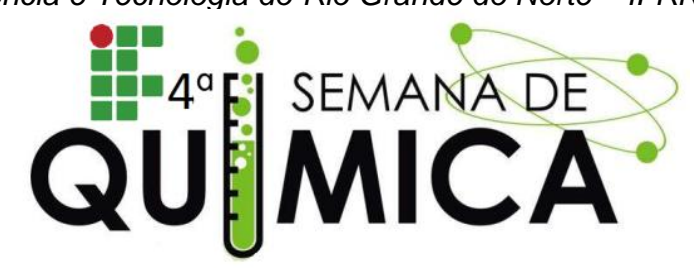

\title{
DESENVOLVIMENTO DE RECURSOS DIDÁTICOS PARA O ENSINO DE DESENHO INDUSTRIAL A PORTADOR DE DEFICIÊNCIA VISUAL
}

\author{
OLIVEIRA, S. A. (IFRN - NC); COSTA, A. V. L. (IFRN - NC); SILVA, M. F. (IFRN - NC)
}

Palavras Chave: deficiência visual, desenho industrial, material didático.

\section{INTRODUÇÃO}

A representação em um desenho de um objeto tridimensional através da projeção isométrica é um desafio para muitos estudantes vidente. Para um estudante portador de deficiência visual se torna imprescindível à utilização de recursos didáticos diferenciados para que este consiga entender e interpretar esse tipo de representação.

Este presente trabalho via descrever o desenvolvimento de recursos didáticos utilizados na disciplina de desenho industrial do curso de Tecnologia de Processos Químicos Industriais para um portador de deficiência visual.

\section{METODOLOGIA}

Para que o estudante com deficiência visual conseguisse compreender a representação da projeção isométrica, se fez uso de sólidos geométricos de acrílicos que eram usados nas aulas de matemática para o ensino médio. Além da confecção de um material de didático que consiste nos desenhos em alto relevo, com a respectiva legenda em Braille desses sólidos em um papel apropriado, ver Figura 1

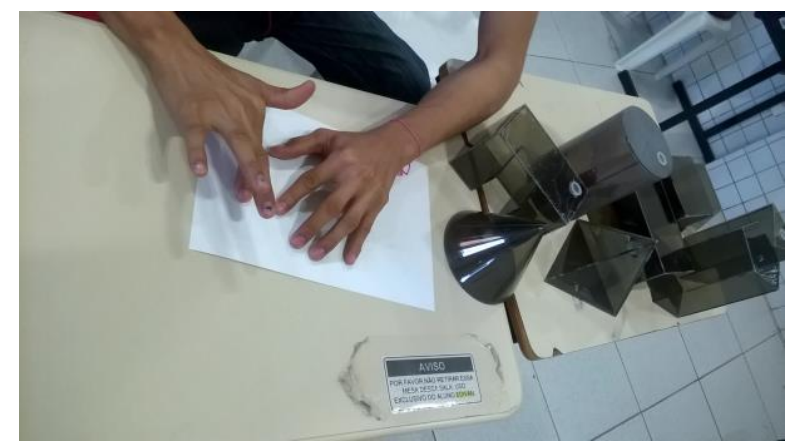

Figura 1 - Sólido geométricos e desenho em alto relevo
Após essa etapa, se fez uso de um desenho em alto relevo na projeção isométrica e vistas ortogonais de um dos sólidos geométricos, ver Figura 2.

\begin{tabular}{|l|}
\hline Espaço destinado a \\
fixaçâo no pôster de uma \\
cópia em alto relevo do \\
material didático \\
\\
\end{tabular}

Figura 2 - Desenho isométrico em alto relevo

A próxima etapa é a confeç̧ão de um protótipo de régua tátil (Figura 3) que usa sistema Braille em uma impressora 3D, para que o estudante consiga realizar medidas básicas nos objetos de estudo.

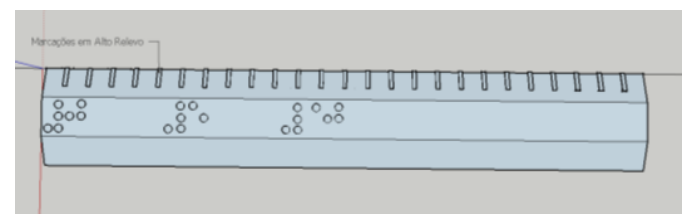

Figura 3 - Protótipo de uma régua tátil

\section{RESULTADOS, DISCUSSÕES}

O presente trabalho encontra-se em andamento. Porém ainda que nas etapas preliminares $o$ estudante tem demostrado desenvolvimento na compreensão espacial e de representação do desenho industrial.

\section{REFERÊNCIAS}

VIGINHESKI, Lúcia Virginia Mamcasz et al . O sistema Braille e o ensino da Matemática para pessoas cegas. Ciênc. educ. (Bauru), Bauru, v. 20, n. 4, p. 903-916, Dec. 2014 
